\title{
Lidil
}

Revue de linguistique et de didactique des langues

$41 \mid 2010$

Énonciation et rhétorique dans l'écrit scientifique

\section{Impersonality and Grammatical Metaphors in Scientific Discourse}

The Rhetorical Perspective

\section{Zohar Livnat}

\section{OpenEdition}

\section{Journals}

Édition électronique

URL : http://journals.openedition.org/lidil/3015

DOI : $10.4000 /$ lidil.3015

ISSN : 1960-6052

Éditeur

UGA Éditions/Université Grenoble Alpes

Édition imprimée

Date de publication : 30 mai 2010

Pagination : 103-119

ISBN : 978-2-84310-167-0

ISSN : 1146-6480

Référence électronique

Zohar Livnat, «Impersonality and Grammatical Metaphors in Scientific Discourse », Lidil [En ligne],

41 | 2010, mis en ligne le 30 novembre 2011, consulté le 01 mai 2019. URL : http://

journals.openedition.org/lidil/3015; DOI : 10.4000/lidil.3015

(C) Lidil 


\title{
Impersonality and Grammatical Metaphors in Scientific Discourse
}

\author{
The Rhetorical Perspective
}

\author{
Zohar Livnat
}

\begin{abstract}
Corpus-based research of scientific articles in the social sciences in Hebrew demonstrates different kinds of impersonal constructions characteristic of this genre, among them various uses of grammatical metaphors. An analysis of this data from the rhetorical perspective makes it possible to point to the rhetorical roles performed by impersonal constructions. They serve the 'rhetoric of objectivity' and the ethos of the credible and uninvolved researcher, and present the research as an entity independent of and separate from the researcher. The author's absence from the cognitive actions that underlie the text, in particular the drawing of conclusions, presents the conclusions as those that any rational reader would draw given the same data. Impersonal constructions involve the reader in the cognitive activities that underlie the scientific paper and create common ground between the writer and reader. Viewed from the rhetorical perspective, grammatical metaphors appear to be rhetorical devices that serve the entire range of goals of the author, as a member of the scientific community.
\end{abstract}

\section{RÉSUMÉ}

Cette recherche, basée sur un corpus d'articles scientifiques en sciences sociales rédigés en hébreu, se donne pour objectif d'identifier différentes formes de constructions impersonnelles du genre, dont en particulier l'utilisation des métaphores grammaticales. L'analyse, menée dans une perspective rhétorique, permet de dégager les fonctions rhétoriques de ces constructions impersonnelles, mises au service de la «rhétorique de l'objectivité » en renforçant la crédibilité du chercheur, non impliqué dans son discours. Cette absence formelle de l'auteur dans son raisonnement, en particulier dans la partie finale, donne au lecteur un

* Bar-Ilan University, Israel. 
sentiment d'évidence vis-à-vis des conclusions tirées de l'analyse des données. Les constructions impersonnelles impliquent ainsi le lecteur dans les actions cognitives, créant un terrain commun entre l'auteur et le lecteur. Vues sous l'angle rhétorique, les métaphores grammaticales servent les objectifs rhétoriques de l'auteur en tant que membre de la communauté scientifique.

\section{Scientific discourse as argumentation}

The discourse of scientific papers is an argumentative discourse whose purpose is to persuade the scientific community to accept the new knowledge and arguments presented in them and make them part of the 'scientific knowledge' or 'facts' upon which there is a consensus within the relevant discipline. An academic career in any field is dependent on the publication of papers, and these papers must be published in peerreviewed journals, after having been studied and assessed by members of the same disciplinary community. The researcher's reputation is built up over time through the publication of his work and by the degree and extent to which the other members of the community cite and use it. Consequently, some evidence of the author's effort to persuade the readers should be found in every scientific text of this kind. Persuasion is relevant at two stages: At the first stage the author needs to convince the editors of the journal to accept the paper for publication, and at the second the members of the disciplinary community have to accept the new arguments and make them part of the accepted knowledge base shared by that community. Because the scientific article is a written product, the testimony to the author's persuasive efforts is by definition linguistic and textual in nature. A rhetorical linguistic analysis of the text should take an in-depth look at the linguistic details in the context of the author's aims. Sociologists, anthropologists and historians of science, such as Latour \& Woolgar (1979), Bazerman (1988), Shapin (1984), among others, have provided excellent descriptions of the scientific text from a social perspective and its role within the disciplinary discourse community. However, a thorough examination of the linguistic items and of their unique role in scientific discourse should naturally be the work of linguists and discourse analysts.

According to the modern approach to science, in order for research to be viewed as 'scientific', it must be replicable with similar results. Among the requirements of the Popperian criterion of falsifiability is the feasibility of repeating the procedure as reported by the researcher. 
The criterion of falsifiability says that "statements or systems of statements, in order to be ranked as scientific, must be capable of conflicting with possible, or conceivable, observations." (Popper, 1963, p. 39.) As Bazerman noted, "The original report of an experiment or observation will not necessarily establish for all lookers the existence and character of a phenomenon, though the authors might wish so." (Bazerman, 1988, p. 309.) Consequently, the authors need to create the impression that what they are describing is a stable phenomenon that can be faithfully replicated.

If research is to be perceived as that which can be precisely replicated, it must appear to be completely independent of the identity, personality or specific circumstances of the researcher carrying it out. To attain this end, a deliberate effort is made in scientific discourse to diminish the researcher's presence in the text, resulting in an 'objective' style of writing that ostensibly enables the facts to 'speak for themselves'. Daston (1992) suggests that the kind of objectivity that is relevant to scientific activity is an aperspectival objectivity, which is related to the ethos of the interchangeable and therefore featureless observer. The ideal observer has no particular characteristics which interfere with the transmission of the results or the comparison between results obtained in a different place, at a different time and by different researchers. This then, creates an impression of objective reporting, the 'rhetoric' of objectivity.

It is important to mention that disciplines in the academe are considered "subcultures" (Clark, 1962) or "tribes" (Becher, 1981, p. 121), each one having its own particular qualities, norms, practices and a relatively stable rhetorical situation (Hyland, 1998, p. 20). Thus, the means by which arguments are presented, procedures enumerated, literature cited, theory and data discussed can only be seen as effectively persuasive against a backdrop of disciplinary practices and rhetorical expectations (Hyland, 1998). Research in academic writing in the past decade has established that scientific discourse is not a monolithic, uniform form of discourse but varies according to disciplinary conventions and cultural expectations (Hyland, 2006). Research investigating English scientific writing has demonstrated a long list of variations across disciplines, including argumentative moves (Holmes, 1997), authorial stance (Kuo, 1999; Bondi, 2005; Groom, 2005), speech acts (Myers, 1992), pronouns (Kuo, 1999; Fløttum et al., 2006), self-citation (Hyland, 2001, 2003; Fløttum et al., 2006), hedging and mitigation (Hyland, 1998; Vold, 2006), critical and evaluative expressions (Stotesbury, 2006), 
adversatives (Fløttum et al., 2006), questions (Hyland, 2002), negation (Fløttum et al., 2006) and meta-text (Samson, 2004; Bondi, 2005).

Scientific objectivity is primarily associated with the natural sciences, while both its possibility and desirability in the social sciences have been the subject of controversy since the turn of the $20^{\text {th }}$ century (Daston, 1992, p. 599). In the social sciences, the status of objectivity as a value in of itself is different from its position in the natural sciences. In one example, Geertz (1988) describes the strength of anthropological research as stemming from the very presence of the researcher in the research field and the reader's feeling that the researcher was himself "there". At the same time, it would appear that the desire on the part of the humanities and social sciences to prove themselves as having scientific validity causes them to adopt the linguistic, stylistic and rhetorical norms that historically developed in the natural sciences.

One of the most important linguistic characteristics of objective reporting is its impersonal nature. Hyland (2002) noted that "impersonality is seen as a defining feature of expository writing as it embodies the positivist assumption that academic research is purely empirical and objective" (Hyland, 2002, p. 1095). Discussing different genres, Berman (forthcoming) notes that "the favoring of impersonal constructions in expository prose is a general feature of this type of discourse." She proposes "a discourse-based continuum of impersonalization, extending out to interactive conversation at one end, via personal experience and fictive narratives, to informative texts, expository discussions and research papers, at the other." (See also Kupersmitt, 2006; Reilly et al., 2002.)

In the following sections, I will demonstrate some of the linguistic constructions involved in creating an impersonal tone in scientific discourse in Hebrew, and will relate to them from the rhetorical perspective. The examples are taken from a corpus of 30 scientific articles in the social sciences published in Hebrew in Megamot in 1999-2000. The average length of the articles is about 18 pages of text, and in total, the corpus includes 534 pages of text. Megamot is a scientific periodical in the behavioral sciences, which since 1972 has published papers on varied subjects, such as education, sociology, anthropology, psychology, political science, administration, organizational behavior, communications and more. The periodical is refereed (anonymous refereeing), and it declares that in order to be considered worthy of being published in it, all papers must meet the highest standards of scientific writing in the behavioral sciences. Because Israeli scholars are required 
to publish their papers mainly in English, Israel does not have a wide selection of Hebrew-language periodicals in these fields, and among them, Megamot is considered the best platform for scientific publication. The papers that are published are very different from one another in many of their features. They range from reports on empirical studies, which bear a strong resemblance to papers from the fields of the life sciences, to papers that offer theoretical models and philosophical papers that deal mainly with content analysis. Most of the papers in the corpus focus on the analysis of quantitative data, although the corpus also contains studies that use only qualitative research methodologies. This corpus offers the researcher a wide selection of linguistic means to achieve various rhetorical aims. In this paper, I will focus on the means of impersonal expression.

\section{Rhetoric of objectivity and impersonality}

In this paper, I have adopted a wide semantic-pragmatic definition of 'impersonality' as the reverse of 'agency' (Yamamoto, 2006), rather than a narrow grammatical one. According to this definition, an impersonal construction is any construction that enables the speaker to refrain from explicit indication of the agent.

Languages differ in the ways they downgrade agency and express an impersonal stance. There are also differences in the presence and frequency of the available constructions across contexts and genres. Since Hebrew is tolerant of subjectless constructions, Hebrew speakers rely on a rich range of options -subjectless $3^{\text {rd }}$ person plural, subjectless modal operators, generic $2^{\text {nd }}$ person subject, intransitive verbs and passive voice constructions (Berman, forthcoming; Berman, 2004; Ravid \& Zilberbuch, 2003). "Reliance on subjectless constructions for expressing an impersonal stance" is "an important feature of Hebrew typology from early on in development" (Berman, forthcoming).

Subjectless $3^{\text {rd }}$ person plural constructions, although an available tool for Hebrew speakers, are not frequent in scientific discourse in Hebrew (Livnat, forthcoming). Fourteen examples were found in the corpus, three of them appear in temporal clauses and ten in conditional subordinate clauses, as demonstrated in examples (1)-(2):

(1) ka'asher bochanim et aksharim [...] (711).

' when examine + PLUR the connections $[\ldots]=$ when one examines the connections...' 
(2) im mekablim et megamot atmi'a [...] (12).

'if accept + PLUR the absorption trends $[\ldots]=$ if one accepts the absorption trends...'

Much more common are subjectless modal or evaluative operators, and passive forms (Livnat, 2006). The former is typical of Hebrew in general while the latter is assumed to be influenced by its frequency in English. In this section, I will demonstrate their use and rhetorical effect in scientific discourse.

\section{modal/evaluative operator + infinitive}

Modal and evaluative operators are predicative constituents of a sentence nucleus, whose other constituent is or centers upon an infinitive (Rosén, 1977, p. 113). Consider the following examples:

(3) meha'amur la'eil nitan lehasik she-eichut hainteraktsia [...] (74). 'From the above possible to conclude that the quality of $[\ldots]=$ from the above it can be concluded that...'

(4) efshar im kach leha'arich ki shloshet hamarkivim [...] (24). 'possible thus to conjecture that the three elements $[\ldots]=$ it thus may be conjectured...'

(5) min hahagdarot halalu kal lir'ot she-ta'ut medida [...] (60). 'From these definitions, easy to see that a mistake $[\ldots]=$ from these definitions, it is easy to see that...'

In these examples, modal operators such as nitan ('possible') or efshar ('possible'), and evaluative adjectives such as kal ('easy') together with the infinitives lehasik ('to conclude'), leha'arich ('to conjecture'), lir'ot ('to see'), create a purely subjectless construction where no agency is involved. The translations into English add the expletive subject 'it', although this is not only not required, it is generally inadmissible in Hebrew (as in other languages tolerant of subjectless constructions, such as Spanish or Polish) (Berman, forthcoming).

A corpus-based analysis of scientific articles in Hebrew (Livnat, forthcoming) found this construction to be a powerful tool for establishing an impersonal tone in this genre. It has 333 occurrences in the corpus, $53 \%$ of which include the modal operator nitan (see example 3 above). Its rhetorical importance is related to its impersonal quality. For instance, by using the phrase nitan lehasik ('possible to conclude') the author implies that the cognitive act of concluding is not an action that he performs from his personal point of view, but an action that 
can be performed by every reader, or better -by every rational member of the scientific discourse community. The impersonal quality of this construction not only downgrades the author's presence in the text but also imbues some of the author's cognitive actions with the potential to include the reader as well, thereby inviting the reader's participation in the cognitive actions of identification, analysis, generalization, drawing conclusions, etc. The result could be to enable the reader to experience these actions as if she is carrying them out herself. This resembles the use of the inclusive first-person plural, 'we', which achieves a similar result. 'We see' or 'We conclude' might be experienced as actions that the writer and reader carry out together.

\section{Passive voice}

Passive forms are far less common in Hebrew than in English. Jisa et al. (2002) found that English makes much greater use of the passive voice for agency downgrading compared to Hebrew, although Hebrew also has structurally productive passive voice constructions. The difference in usage can be explained in terms of availability of alternative rhetorical options to express the same discourse function (Berman, forthcoming). Nevertheless, in my corpus, 1092 passive verbs were found denoting the researcher's actions. The large distribution of passive forms in scientific discourse in Hebrew seem to be influenced by English in its role as the lingua franca of academia. Israeli researchers writing in Hebrew in the social sciences read (and also write) most of the relevant literature in English. Passive forms appear in all parts of scientific papers in Hebrew, seemingly reducing the part played by the researcher who actually carried out each of the different actions: formulating the assumptions, gathering the data, providing interpretation of the findings, drawing conclusions and ultimately -writing the text. Examples (6)-(9) demonstrate these various activities.

Passive relating to hypotheses:

(6) kfi she-sho'ar, divuchey morim chasfo kama hevdelim [...] (94). 'As was assumed, teachers' reports revealed a number of differences...'

Passive relating to the actual performance of the study:

(7) al menat le'emod et meheimanut hakriteryon ne'esfu netunim al tsiyunei kursim beshana alef [...] (61).

'In order to estimate the reliability of the criterion, data were collected on the course marks in the first year...' 
Passive relating to the analysis of findings:

(8) lo nimtse'u hevdelim bein yeladim bakvutsot hakliniyon [...] (88). 'No differences were found between children in the clinical groups...'

Passive relating to meta-text, i.e. to the act of writing:

(9) kfi she-yusbar lehalan [...] (39).

'As will be explained below...'

I will discuss in the following section additional elements that are involved in creating an impersonal tone. These will be discussed in the framework of "grammatical metaphor" suggested by Halliday (2004).

\section{Grammatical metaphors in scientific language}

In his work on scientific discourse, Halliday (2004) developed the concept of "grammatical metaphor." While in classical (lexical) metaphor one word takes over from another, in grammatical metaphor one grammatical class takes over from another (Halliday, 2004, p. 38), as a way of "reconstructing the relations between the grammar and the semantics" (ibid., p. 107). Thus, metaphor in the grammatical sense is the replacement of one grammatical class by another.

Halliday's assumption is that ordinary everyday language, such as that found in the language of young children before they move from commonsense knowledge to educational knowledge, is constructed by what he calls 'congruence'. In the congruent mode of language, nouns represent things, verbs represent happenings, adjectives represent qualities and connectors represent logical relations. However, the relationship between grammar and semantics can be more complicated. In the incongruent mode of language, qualities might be realized by nouns, happenings by nouns or adjectives, and logical relations by verbs.

The prototypical example of grammatical metaphor is nominalization. For example, an element having the nature of an action might be given a nominal form, and in this way, the language reorganizes 'happenings' as if they were 'things'. The incongruent mode of language was identified by Halliday as a clear linguistic feature of English scientific discourse, having its origins in the history of scientific English. "This probably started, or at least first reached a significant scale, with nominalization: decoupling 'qualities' and 'processes' from their congruent realizations as adjectives and verbs, and recoupling both these mean- 
ings with nouns." (Ibid., p. XVI.) According to Halliday, nominalization "is motivated in the discourses of science, because of its massive potential for creating new knowledge" (ibid., p. XxI). "Grammatical metaphor increases the power that a language has for theorizing, because it creates virtual phenomena -virtual entities, virtual processes- which exist solely on the semiotic plane; this makes them extremely powerful abstract tools for thinking with." (Ibid., p. XVII.)

According to Halliday, the wide distribution of grammatical metaphors in scientific discourse has various causes or 'pay-offs'. First, they serve to 'construe technicality'. Since the nominal group is the most powerful resource for creating taxonomies (categories and subcategories), nominalization helps to create technical meaning through 'Classifier + Thing' structures (ibid., pp. 38-39). Second, by reconstructing qualities, processes and logical relations as 'things', the grammar creates a semiotic universe of 'things' (ibid., p. 47). Once qualities, processes and logical relations have taken on the feature of 'entity', the researcher can observe, measure and experiment with them. "It is holding the world still, giving it stability and permanence" (ibid., p. 129).

Moreover, nominalization serves the movement from Theme to Rheme, which is characteristic of scientific discourse as a chain of reasoning. As 'things', "they have the power of entering as participants into the full range of participant roles that the grammar has created for "things"" (ibid., p. 44). Nominalization "allows any observation, or series of observations, to be restated in summary form -compressed, as it were, and packaged by the grammar- so that it serves as the starting point for a further step in the reasoning." (Ibid., pp. 19-20.) The Theme is the stable part, and so it is typically construed as a noun, which is a result of packaging preceding information. Here is one of Halliday's examples, from a microbiology text:

(10) When a solution of any substance (solute) is separated from a solute-free solvent by a membrane that is freely permeable to solvent molecules $[. .$.$] , the solvent tends to be drawn through the$ membrane into the solution, thus diluting it. Movement of the solvent across the membrane can be prevented by applying a certain hydrostatic pressure to the solution.

The verbal phrase "the solvent tends to be drawn through the membrane' in the first sentence is reconstrued as a noun phrase in the second sentence: 'Movement of the solvent across the membrane'. The noun 
phrase is a grammatical metaphor which " "packages' the preceding assertion to function as a point of origin for the next" (ibid., p. 20). The thematic packaging of the information makes the logical progression of the argument possible.

Example (11) is another case of the use of a grammatical metaphor in scientific argument, taken from my corpus and translated into English.

(11) This study shows that the immigrants continued to put in an effort to improve their mastery of Hebrew [...]. However, despite the increase in their Hebrew skills, the study found that the immigrants made use of Hebrew mainly in "formal" circumstances, such as at work.

The noun 'increase' (= 'alya) in the second sentence is an example of a nominalization, since 'increase' is not an entity but rather a process that has been observed by the researcher. This process is one of the research findings described in the first sentence, where it is the focus of the sentence and performs a rhematic function as the new information delivered by the sentence. In the second sentence, this increase is given a definite noun form, placed in a thematic role as the given information. To this given information, new information is added -additional findings that give a new interpretation to the preceding findings. Thus, from the point of view of discourse structure, nominalization serves the development of the argument.

Although nominalization is predominant in the sense that most metaphoric shifts shift into a nominal group, it is not the only one. Halliday has found no less than 13 different metaphoric movements (see table on pp.41-42), evincing a unified direction from the abstract to the concrete. "The general drift is, in fact, a drift towards the concrete, whereby each element is reconstrued in the guise of one that lies further towards the pole of stability and persistence through time" (ibid., p. 43). Another important metaphoric transformation is reconstruing a relator (a logical-semantic relationship) as a verb, i.e. as a 'process' or a 'happening'.

In the next section, I will refer to additional types of phenomena that might be considered grammatical metaphors, although Halliday did not specifically mention them. My discussion will tie them to the 'rhetoric' of scientific discourse and to the rhetorical effect of impersonality. 


\section{Grammatical metaphors and impersonality}

Let us consider metonymies such as 'this paper argues...' instead of 'in this paper I argue...', where 'the paper' is positioned as agent. This construction is demonstrated in examples (12)-(15) below.

(12) ha-ma'amar dan bemashmaut mimtsa'im ele [...] (131).

'The paper discusses the meaning of these findings...'

(13) al smach nituach ha-mikre [...] matsi'a avoda zo histaklut acheret [...] (587).

'Based on an analysis of the case [...] this study proposes a different perspective...'

(14) ha-diyun mitmaked be'ikar bahitnahaguyot shehutsgu [...] (531).

'The discussion focuses mainly on the behaviors presented...'

(15) ha-nituach hanochechi [...] bochen she'ela zo toch pikuach [...] (58).

'The current analysis [...] explores this question while maintaining...'

In this wording, inanimate subjects (paper/study/discussion/analysis) take verbs of cognitive activities as their predicates. Different studies that have investigated the prevalence of such metonymies in scientific English offer varying results. Myers (1992) found that such constructions are infrequent, and he treated them as a marginal phenomenon. Swales (1990), on the other hand, maintains that they are in fact quite prevalent in English, while noting that in some languages, such as Japanese, formulations of this kind are unacceptable. Hebrew is apparently one of the languages in which this structure is more frequently found. In my corpus, all the papers contain sentences of this kind, in particular in the introductory and concluding sections.

The crucial point from a rhetorical perspective is that this kind of grammatical metaphor, one that positions the paper/study/discussion/ analysis as a metonymic agent, has an impersonal quality. Since the actions of discussing, proposing, focusing and exploring are all cognitive activities carried out by the researcher himself, the grammatical metaphor enables him to refrain from indicating the actual agent, thereby downgrading the author's presence in the text.

Not only does the use of such metonymies fulfill the purpose of creating an impression of objectivity, it also creates distance between the researcher and the research, positioning the study as an entity separate from the researcher carrying it out. Presenting the research as an 
independent entity, in addition to the distinction "between the individual and the work done by him, provides an important resource in the construction of facts" and is used persuasively (Latour \& Woolgar, 1979, p. 188).

Particular note should be paid to the ways in which the act of drawing conclusions is presented. In scientific discourse, it is common practice to use formulations of drawing conclusions in such a way as to present the drawing of conclusions not as a process carried out by the researchers, but rather as an integral feature of nature. Conclusions "are made to appear as if they followed unproblematically from empirical evidence" (Hyland, 1998, p. 18). Such formulations also have the effect of obscuring the presence of the researcher because they point to a truth that arises from the reality itself rather than from the manner in which the researcher perceives it.

Several kinds of grammatical metaphors may be involved in such a wording. Examples (16)-(19) demonstrate the use of scientific language in verbs such as 'indicate', 'reveal', 'show' and 'give rise'.

(16) bdikat hanetunim [...] matsbi'a 'al dimyon [...] (142). 'An examination of the data [...] indicates the similarity...'

(17) ha-nituach she-butsa be ikvot mimtsa ze chasaf hevdelim [...] (91). 'The analysis carried out in the wake of this finding revealed differences...'

(18) bchinat hamegamot hamistamnot [...] her'ata ki hadfus hashachiach [...] (258).

'An investigation of the trends that emerge $[\ldots]$ showed that the common pattern...'

(19) hitbonenut bechelko ha'elyon shel luach 3 ma'ala ki [...] (142). 'Observation of the upper part of Table 3 gives rise [to the conclusion] that...'

None of these verbs indicates an action or occurrence in this context; rather, they express the logical relationship of premise and conclusion. This is a metaphoric transformation, whereby the relator (the logicalsemantic relation) is reconstrued as a verb, i.e. as a 'happening'. And while the logical-semantic relation is construed as a verb, the action

1. The Hebrew word maskana [= conclusion] is historically derived from the Aramaic root $s l k$ [= rise, arise]. In Modern Hebrew the common collocation is 'the conclusion arises from the data' (Livnat, forthcoming). 
being taken by the researcher is construed as a noun (examination/ analysis/investigation/observation) and takes the syntactic role of the subject.

From a rhetorical perspective, the crucial point is that despite the fact that the nouns represent actions that the researcher carries out as part of her scientific work, this formulation manages to create the impression that it is not an action performed by and dependent on an observer, but rather that it is the necessary conclusion that naturally arises from the data. Here is yet another example, the verb movil ('lead'):

(20) mimtsa'ei hamechkar hanochechi movilim lamaskana [...] (677).

'The findings of the current study lead to the conclusion that...'

The syntactic structure of this example provides an outstanding exemplification of the structure of a logical argument, as illustrated in (20a).

(20a) P (= premise: the findings of the current study)

-- $\quad(=$ then: lead to $)$

Q (= conclusion: the conclusion that)

The findings fulfill the function of the premise, from which the conclusion must follow. The premise, which is presented by means of the noun phrase 'the findings of the current study', occupies the position of the syntactical subject. The conclusion occupies the position of the object, and the verb 'lead' signifies the logical connection between the premise and the conclusion. Within this tight logical construction, there is no room for an observer who draws conclusions based on findings. Thus, the drawing of conclusions seems to occur 'on its own', without any intervention on the part of the researcher. A grammatical metaphor of this kind thus enables the researcher's absence, and makes it possible to present conclusions and inferences not as a result of a cognitive activity carried out by the author, but rather as something that arises naturally and unproblematically from the data.

The use of abstract nouns such as 'examination' (ex. 16) or 'observation' (ex. 19), rather than verbs ('examine', 'observe') has additional rhetorical importance. As an impersonal element, it extends the agent of the action to include the reader too. In this way, the researcher, who is in fact performing the 'examination' or 'observation' activity, invites the reader to carry it out together with her, and in this way, to reach the same conclusions. This feeling of sharing and involvement in the thinking process can enable the reader to draw intellectual pleasure from the reading of the paper and from the way in which the new argument 
is constructed. This pleasure can increase the reader's positive feelings towards the paper and the arguments presented in it, and thereby increase the chances of the arguments being accepted and becoming part of the shared disciplinary body of knowledge.

\section{Conclusions}

Corpus-based research of scientific articles in the social sciences in Hebrew demonstrates different kinds of impersonal constructions characteristic of this genre, among them subjectless modal operators, the passive voice and various uses of grammatical metaphors. An analysis of this data from a rhetorical perspective makes it possible to point to the rhetorical roles performed by impersonal constructions.

First, they serve the 'rhetoric of objectivity' and help to enhance the ethos of the credible and uninvolved researcher. The absence of the author from the cognitive actions that underlie the text, in particular the drawing of conclusions, is especially important. This rhetorical device presents the conclusions as having been drawn 'naturally', as if they arise all on their own from the data, i.e. a conclusion that every rational reader should reach given the same data.

Metonymies that position inanimate subjects as agents of cognitive activities serve to create an impression of separation of the research from the researcher, and to present the research as an independent entity. By using this kind of grammatical metaphor, the author can distance herself from the research and let the findings 'speak for themselves'.

Another rhetorical outcome is the possibility of having the reader share in the cognitive activities that underlie the scientific paper and experience them by himself. In this way, the author creates common ground between herself and the reader, which is a major rhetorical device for the creation of agreement. Viewed from the rhetorical perspective, grammatical metaphors appear not only as an inherent characteristic of scientific language, but mainly as a rhetorical device that serves the entire range of goals of the author as a member of the scientific community. 


\section{BIBLIOGRAPHICAL REFERENCES}

Bazerman C. (1988): Shaping Written Knowledge: The Genre and Activity of the Experimental Article in Science, The University of Wisconsin Press.

BECHER T. (1981): "Towards a definition of a disciplinary cultures", Studies in Higher Education, vol. 6, no. 2, pp. 109-22.

BERMAN R. (2004): "Between emergence and mastery: The long developmental route of language acquisition", In R. Berman, Language development across Childhood and Adolescence, Amsterdam, John Benjamins, pp. 9-34.

BERMAN R. (forthcoming): "Revisiting impersonal constructions in Hebrew: Discourse-based perspectives", In A. Malchukov and A. Siewierska (eds), The Typology of Impersonal Constructions.

Bondi M. (2005): "Metadiscursive practices in academic discourse: Variations across Genres and Disciplines", In J. Bamford and M. Bondi (eds), Dialogue within Discourse Communities, Tubingen, Niemeyer, pp. 3-30.

Clark B.R. (1962): Faculty Culture, Berkeley, Center for the Study of Higher Education, University of California.

DASTON L. (1992): "Objectivity and the escape from perspective", Social Studies of Science, vol. 22, no. 4, pp. 597-618.

Fløтtum K., Dahl T., and Kinn T. (2006): Academic Voices, Amsterdam/ Philadelphia, John Benjamins.

GeERTz C. (1988): Works and Lives: The Anthropologist as Author, Stanford, Stanford University Press.

Groom N. (2005): "Pattern and meaning across genres and disciplines: An exploratory study", Journal of English for Academic Purposes, vol. 4, no. 3, pp. 257-77.

HallidaY M.A.K. (2004): The Language of Science, New York/London, Continuum.

Holmes R. (1997): "Genre analysis and the social sciences: An investigation of the structure of research article discussion sections in three disciplines", English for Specific Purposes, vol. 16, pp. 321-37.

Hyland K. (1998): Hedging in Scientific Research Articles, Amsterdam/ Philadelphia, John Benjamins.

Hyland K. (2001): "Humble servants of the discipline? Self-mention in research articles", English for Specific Purposes, vol. 20, pp. 207-26.

Hyland K. (2002): "Authority and invisibility: Authorial identity in academic writing", Journal of Pragmatics, vol. 34, pp. 1091-112.

Hyland K. (2003): "Self-citation and self-reference: Credibility and promotion in academic publication", Journal of American Society for Information Science and Technology, vol. 54, no. 3, pp. 251-59. 
HYLAND K. (2006): "Disciplinary differences: Language variations in academic discourses", In K. Hyland and M. Bondi (eds), pp. 17-45.

Hyland K. and Bondi M. (eds) (2006): Academic discourse across disciplines, Bern, Peter Lang.

Jisa H., Reilly J.S., Verhoeven L., Baruch S., and Rosado E. (2002): "Passive voice constructions in written texts: A cross-linguistic developmental study", Written Language \& Literacy, vol. 5, pp. 163-282.

Kuo C.H. (1999): "The use of personal pronouns: role relationships in scientific journal articles", English for Specific Purposes, vol. 18, no. 2, pp. 121-38.

KuPERSMITT J. (2006): Temporality in texts: A crosslinguistic study of formfunction relations in narrative and expository discourse, Bar Ilan University, unpublished doctoral dissertation.

Latour B. and Woolgar S. (1979): Laboratory life: The Social Construction of Scientific Facts, Beverly Hills, Sage.

Livnat Z. (2006): "La rhétorique de l'objectivité: le rôle de l'auteur dans l'écriture scientifique", Questions de Communication, no. 9, pp. 95-121.

Livnat Z. (forthcoming): Persuasive methods of scientific discourse: The speaker, audience and the social role of the scientific article, Bar Ilan University Press.

MYERS G. (1992): “'In this paper we report...': Speech acts and scientific facts", Journal of Pragmatics, vol. 17, pp. 295-313.

PoPper K. (1963): Conjectures and Refutations, London, Routledge and Kegan Paul.

Ravid D. and Zilberbuch S. (2003): "Morpho-syntactic constructs in the development of spoken and written Hebrew text production", Journal of Child Language, vol. 30, pp. 395-418.

Reilly J.S., Baruch E., Jisa H., and Berman R. (2002): "Propositional attitudes in written and spoken language", Written Language and Literacy, vol. 5, pp. 183-218.

Rosén C.B. (1977): Contemporary Hebrew, La Hague/Paris, Mouton.

SAMSON C. (2004): "Some interpersonal meta-discourse aspects in contemporary written economics lectures", In M. Bondi, L. Gavioli, and M. Silver (eds), Academic Discourse, Genre and Small Corpora, Rome, Officina Edizioni, pp. 71-85.

SHAPIN S. (1984): "Pump and circumstance: Robert Boyle's literary technology", Social Studies of Science, vol. 14, pp. 481-520.

Stotesbury H. (2006): "Gaps and false conclusions: Criticism in research article abstracts across the disciplines", In K. Hyland and M. Bondi (eds), pp. 123-48. 
Swales J.M. (1990): Genre Analysis. English in Academic and Research Settings, Cambridge/New York / Melbourne, Cambridge Univ. Press.

Vold E.T. (2006): "The choice and use of epistemic modality markers in linguistics and medical research articles", In K. Hyland and M. Bondi (eds), pp. 225-49.

Yамамото M. (2006): Agency and Impersonality: Their Linguistic and Cultural Manifestations, Amsterdam/Philadelphia, John Benjamins. 